\title{
Hospitalization perceived by children and adolescents undergoing cancer treatment
}

\author{
A hospitalização na percepção de crianças e adolescentes em tratamento oncológico \\ Hospitalización en la percepción de niños y adolescentes en tratamiento oncológico
}

\author{
Raíra Lopes Amaral de Souza ${ }^{a}$ \\ Cintia Flôres Mutti ${ }^{b}$ \\ Raissa Passos dos Santos ${ }^{c}$ \\ Diúlia Calegari de Oliveira ${ }^{\mathrm{d}}$ \\ Aline Cristiane Cavicchioli Okido \\ Leonardo Bigolin Jantsch ${ }^{f}$ \\ Eliane Tatsch Neves ${ }^{\mathrm{a}}$
}

\begin{abstract}
How to cite this article: Souza RLA, Mutti CF, Santos RP, Oliveira DC, Okido ACC, Jantsch LB, Neves ET. Hospitalization perceived by children and adolescents undergoing cancer treatment Rev Gaúcha Enferm. 2021;42:e20200122. doi: https://doi.org/10.1590/19831447.2021.20200122
\end{abstract}

\footnotetext{
Universidade Federal de Santa Maria (UFSM), Programa de Pós-graduação em Enfermagem. Santa Maria, Rio Grande do Sul, Brasil.

b Universidade Federal de Santa Maria (UFSM), Colégio Politécnico, Programa de Pós-graduação em Enfermagem. Santa Maria, Rio Grande do Sul, Brasil.

'McGill University, Ingram School of Nursing. Montreal, Quebec, Canada.

¿Universidade Federal de Santa Maria (UFSM), Graduação em Enfermagem. Santa Maria, Rio Grande do Sul, Brasil

e Universidade Federal de São Carlos (UFSCar), Programa de Pós-graduação em Enfermagem. São Carlos, São Paulo, Brasil.

'Universidade Federal de Santa Maria (UFSM), Departamento de Ciências da Saúde. Palmeira das Missões, Rio Grande do Sul, Brasil.
}

\section{ABSTRACT}

Objective: To know the perception of children and adolescents undergoing cancer treatment about hospitalization.

Methods: Qualitative research conducted with 13 children and adolescents hospitalized for cancer treatment at a referral hospital in southern Brazil. Semi-structured interviews mediated by the drawing technique were conducted from May to November 2018. Data was submitted to inductive thematic analysis based on the theoretical framework of Brazil's National Humanization Policy.

Results: Disturbances were detected in the professionals' communication with the hospitalized children and adolescents. The participants felt socially isolated and highlighted the importance of recreational activities during hospitalization.

Conclusion: Infant cancer is complex and needs multidisciplinary care during the treatment, enabling the organization of healthy and welcoming spaces that favor humanization of care.

Keywords: Pediatric nursing. Adolescent. Medical oncology. Hospitalization. Humanization of assistance.

\section{RESUMO}

Objetivo: Conhecer a percepção de crianças e adolescentes em tratamento oncológico sobre a hospitalização.

Métodos: Pesquisa qualitativa desenvolvida com 13 crianças e adolescentes hospitalizados em tratamento oncológico em um hospital de referência na região sul do Brasil. Foram desenvolvidas entrevistas semiestruturadas mediadas pela técnica do desenho no período de maio a novembro de 2018. Os dados foram submetidos à análise temática indutiva fundamentada no quadro teórico da Política Nacional de Humanização.

Resultados: Apontaram ruídos na comunicação dos profissionais com a criança e adolescente hospitalizado; os participantes sentiam-se isolados socialmente e destacaram a importância de atividades lúdicas durante a hospitalização.

Conclusões: 0 câncer infanto-juvenil é complexo e necessita de um olhar multiprofissional durante seu tratamento, possibilitando a organização de espaços saudáveis e acolhedores em prol da humanização do cuidado.

Palavras-chave: Enfermagem pediátrica. Adolescente. Oncologia. Hospitalização. Humanização da assistência.

\section{RESUMEN}

Objetivo: Conocer la percepción de niños y adolescentes sometidos a tratamiento contra el cáncer sobre la hospitalización.

Métodos: Investigación cualitativa realizada con 13 niños y adolescentes hospitalizados para tratamiento de cáncer en un hospital de referencia en el sur de Brasil. Las entrevistas semiestructuradas se desarrollaron mediadas por la técnica de dibujo de mayo a noviembre de 2018. Los datos se sometieron a un análisis temático inductivo basado en el marco teórico de la Política Nacional de Humanización.

Resultados: Señalaron ruidos en la comunicación de los profesionales con el niño y adolescente hospitalizado; Los participantes se sintieron socialmente aislados y destacaron la importancia de las actividades recreativas durante la hospitalización.

Conclusión: El cáncer para niños y adolescentes es complejo y necesita de una visión multidisciplinaria durante su tratamiento, permitiendo la organización de espacios saludables y acogedores a favor de la humanización de la atención.

Palabras clave: Enfermería pediátrica. Adolescente. Oncología médica. Hospitalización. Humanización de la atención. 


\section{口INTRODUCTION}

According to the Brazilian Society of Pediatric Oncology, childhood cancers differ from adult cancers. Primary sites, histological origins and clinical behaviors are different. Childhood cancer has usually shorter latency periods and often grows rapidly, becoming very invasive, but is more responsive to treatment than adult cancer. Although it is considered a rare disease, cancer is one of the leading causes of death in children and adolescents, both in developed and developing countries ${ }^{(1)}$.

In 1980, neoplasias were the tenth cause of death among children under 19 years old, and in 2016, they became the sixth cause, corresponding, in the national scenery, to approximately $4 \%$ of the total deaths. In Brazil, the estimate for 2020 in the pediatric population is 8,450 new cases of cancer - an estimated risk for this population of 138 cases per million inhabitants. Regarding hospitalizations for treating tumors from January 2008 to December 2016, in the age group of children under 1 year old, the number of hospitalizations was 22,286; from 1 to 4 years, 114,168; and from 5 to 9 years, 111,205 . In the same period, deaths by cancer in the age groups of children under 1 year old were 1,087; from 1 to 4 years,2,491; and from 5 to 9 years,2,646 $6^{(1-2)}$.

Hospitalizations during the treatment and diagnosis period are associated with the needs for treatment, initiation and maintenance of therapy, and with complications that occur during treatment such as possible opportunistic infections, for example. This type of treatment requires frequent attendance or hospitalization of children in specialized health care services. These hospitalizations last for long periods, involve painful and invasive procedures, as well as deprivation of daily routine for children and their families ${ }^{(3)}$.

Diagnosis of cancer and consequent hospitalization of children and adolescents result in limitations in their actions of playing, eating, going to school and interactions with groups of friends and families. Furthermore, experiencing a disease such as cancer implies several adaptations in the lives of patients and their families ${ }^{(4)}$. Hospitalization, in turn, is an unpleasant and stressful experience, which leads children and adolescents to experience feelings of distress, fear and anxiety. Such manifestations are due to the sudden removal of patients from their families and friends, changes in routine and loss of control of their lives ${ }^{(3)}$.

Also, some difficulties in providing care to children with cancer still persist, as follows: difficulties in organizing access to diagnostic tests and treatments, integrating care and research groups, availability of data and evaluation of results. It is also necessary to increase the visibility of policies, involve the various actors and stakeholders and ensure effective accountability ${ }^{(5)}$.

In this regard, it is worth mentioning the National Humanization Policy (PNH) introduced in 2003 with the objective of promoting humanized health practices within the Unified Health System (SUS). Its guidelines include welcoming; expanded clinic; co-management; defense of users' rights; fostering groups, collective constructions and networks ${ }^{(6)}$. The PNH can and should be promoted in the context of the hospitalization of children and adolescents undergoing cancer treatment. Therefore, it provided the theoretical basis for the present investigation.

The issues addressed in this study concern being a child and/or adolescent and developing an oncological disease associated with the fact of being in a phase of growth and development and requiring hospitalization, sometimes prolonged. This is associated with epidemiological data that show the magnitude of cancer, considered a public health problem, the need for integrated treatment and the relevance of providing a humanized hospitalization process. The need for children to be heard involves respecting their singularities. However, most studies and publications on the care of hospitalized children address the perspective of companions or health professionals $s^{(7)}$. Moreover, children and adolescents can and must decide how they want to be cared for and how they can take care of themselves, when they speak and expose their perceptions about the treatment and the conditions imposed. Therefore, the care provided in a pediatric cancer unit demands specificity from the health care team, since patients must be heard, understood, welcomed and respected ${ }^{(8)}$.

In this context, the present study aimed to listen to children and adolescents' views about the experience of hospitalization during cancer treatment, with the purpose of knowing the perception of children and adolescents, who are undergoing cancer treatment, about hospitalization.

\section{METHOD}

Descriptive exploratory qualitative research that used semi-structured interviews mediated by the drawing technique with the children and adolescents who participated in this study, for data production. The use of drawing as a technique for data production was suggested for all participants. However, as the adolescents refused to participate in this proposed activity to mediate the interview, only the children made drawings. The study setting was a hospital service for children and adolescents undergoing hematology-oncology treatment in a general, public, tertiary-level teaching hospital that serves Unified Health System (SUS) 
users exclusively. For more than three decades, this service has been providing care to children and adolescents aged 0-21 years diagnosed with cancer and hematological diseases.

The participants were six children aged 6-12 years and seven adolescents aged 12-18 years, according to the Child and Adolescent Statute, admitted to a pediatric cancer treatment unit in a university hospital in southern Brazil. The number of participants was defined by the data saturation criterion, which is the point at which new data collected and analyzed no longer bring additional insights to answer the proposed objective ${ }^{(9)}$.

The inclusion criteria for the study were confirmed diagnosis of cancer, that is, patients should not be admitted for diagnostic investigation, and the patients must have been hospitalized for treatment for at least one week. Children and adolescents in their first hospitalization, and not only patients with more than one hospitalization, were also included in the study. Exclusion criteria were children and adolescents who had no medical conditions to participate in the research, according to information from the health team of the unit.

The study data were obtained in semi-structured interviews mediated by the drawing technique with children and adolescents. Before data collection, the researcher was given some time to get used to the oncology unit, as she was not familiar with the study setting. Afterwards, a consultation was carried out on the patients' medical records, for the selection of possible participants for the study, according to the selection criteria. A pilot test with a child and a teenager was also carried out, for adjustment of data production aspects. As there were no changes in the instruments and in the approach, the data collected in the pilot test were added to the corpus for analysis. Then, after being previously selected through medical records, legal guardians and participants were invited to participate in the study. First, the parents of the children and adolescents were invited, and after their acceptance, the invitation was made to the research participants, through the signing of the assent form.

Information such as identification, diagnosis, treatment, and sociodemographic data were collected from medical records. The interviews were carried out in the preferred place of the child or adolescent (bedroom, playroom, etc.) by the researcher and recorded for later transcription. In most interviews, the parents or guardians stayed with the children and/or adolescents, and some were absent during this time. As the participants did not object to any of these situations, the interviews were conducted without problems. The interviews lasted in average 6 minutes. The interviews were transcribed twice by two independent transcribers. Data was collected from May to November 2018. Data collection occurred at alternate times of the day, sometimes in the morning and sometimes in the afternoon.

For data analysis, inductive thematic analysis was used, which is a type of content analysis with an accessible and flexible approach, used in the analysis of qualitative data. Inductive thematic analysis is a method for identifying, analyzing and reporting themes (patterns) from the data, which allows them to be organized and described in detail(10).

The study complied with the ethical precepts in research according to the standards and guidelines of Resolution no 466/12 of the National Health Council, and the project was approved by the Research Ethics Committee of Universidade Federal de Santa Maria, under protocol no 857746.8.0000 5346, in March 2018. Participants were identified as C1, C2, ... for children and A1, A2 ... for adolescents.

\section{$\square$ RESULTS}

The participants of the study were 6 children and $7 \mathrm{ad}$ olescents. Of the children, three were male and three were female. Most adolescents were male individuals, with only one female teenager. The children's ages ranged from 7 to 11 years and 9 months. In turn, adolescents' ages ranged from 12 to 17 years.

The oncological diagnoses of children and adolescents were, namely: Leukemias (9), Osteosarcoma (1), Malignant neoplasm of ovary (1), Askin's Tumor (1) and Ewing's Sarcoma (1). Regarding treatment, the use of chemotherapy predominated. The patients were undergoing treatment for 2 months to 4 years. However, some records did not provide complete information about the child and/or adolescent (Treatment History/Stage of Illness). So, a better description of the participants' clinical status was made.

The perceptions of children and adolescents about their hospitalization, under the National Humanization Policy, were presented in three thematic categories: Communication between hospitalized children and adolescents and professionals; Social isolation of children and adolescents during the hospitalization process; and Importance of recreational activities during hospitalization.

\section{Communication between hospitalized children and adolescents and health professionals}

The children and adolescents perceived the communication with the health professionals of the inpatient service as valuable. Health professionals usually do not feel comfortable to speak openly with the patients because they think that children and adolescents cannot understand them. However, both children and adolescents have understanding skills 
according to their age and their length of hospital stay, and this must be recognized and respected by the team.

He (the doctor) spends more time talking to me than talking about exams. (C2)

He (the doctor) speaks in a way that we understand better, you know. I like it. (A11)

Oh, because it was he (the doctor) who came to talk to us. He explained things to us. (A10)

Yes, I already know them all, but when there is a new doctor, they go there to examine me, but the nurses don't. They just measure my blood pressure, check if I have a fever and put that thing on my finger (the patient mentions the oxygen saturation check). (C3)

He comes to talk to the mothers, to explain what is happening. (Referring to the medical professional) (C4)

[...] it's really cool, they are very considerate, always happy. They look happy, they talk, you know. (A11)

The nurses are the people I know best. They are the people I spend most of the time with here. (A10)

The participants showed that they liked to receive explanations from health professionals about routine procedures [intravenous infusion setup, measurement of vital signs, among others) and about their health situation. At the same time, they perceived this as a means of interaction and communication with the team. The recognition of these actions as forms of communication is highlighted in Figure 1.

Based on C9's interpretation of the drawing, it can be seen that she recognizes the health professional and the actions taken by other professionals, who come to "check her vital signs". Moreover, she recognizes herself in one of the hospital routines, such as the infusion of saline solution.

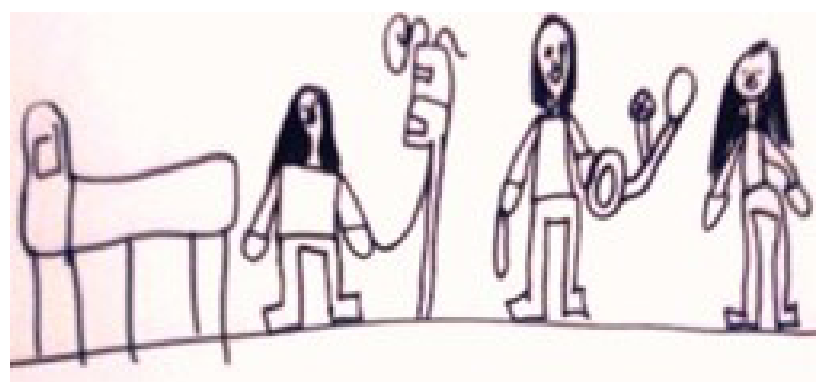

Figure 1 - Drawing made by C9. Seven years old

This is the doctor and, this is my mother [...] I was receiving the medication (serum) and they came to check my condition (C9)

\section{Social isolation of children and adolescents during the hospitalization process}

Hospitalization has a great impact on the social interactions of children and adolescents, as they are removed from their families, friends and school. However, patients' statements in this category also show that children and adolescents understand the hospitalization process.

I feel sad, because I want to go home, but I can't. I need to be treated. But I know that I have to be treated first and then leave hospital. And I will never come back. Except for the appointment. [...]Yes, I would like my whole family to come. And also that ... I could go out, without wearing an ID bracelet, but I agree to take the medicine. (C3)

sad. Why? because I am not with my family. And at home I can be with them. I can play with my friends. I don't want to talk about that. It hurts me a lot. (Referring to the lack of friends). (C2)

"I don't know. It sucks, I can't go out. I can't go to school, I can't go out. (C4)

"Being away from home, right? (A7)

No. I just don't like being locked up here, but it's necessary. (A10)

There's nothing here. Nobody likes to be hospitalized, to be locked up. (A6)

Through drawings (figures 2 and 3), the participants also show their perception about hospitalization.

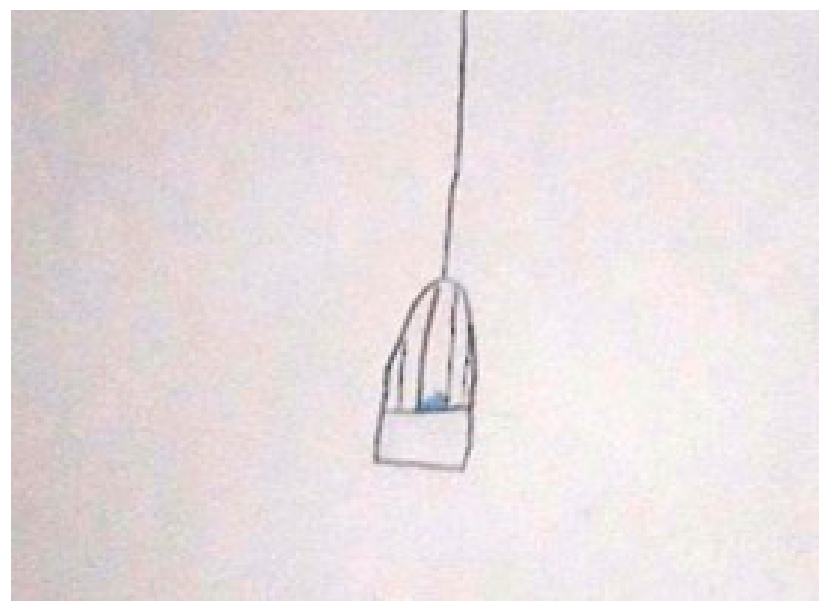

Figure $\mathbf{2}$ - Drawing made by C4. 11 years old

That I feel locked up here. (C4) 


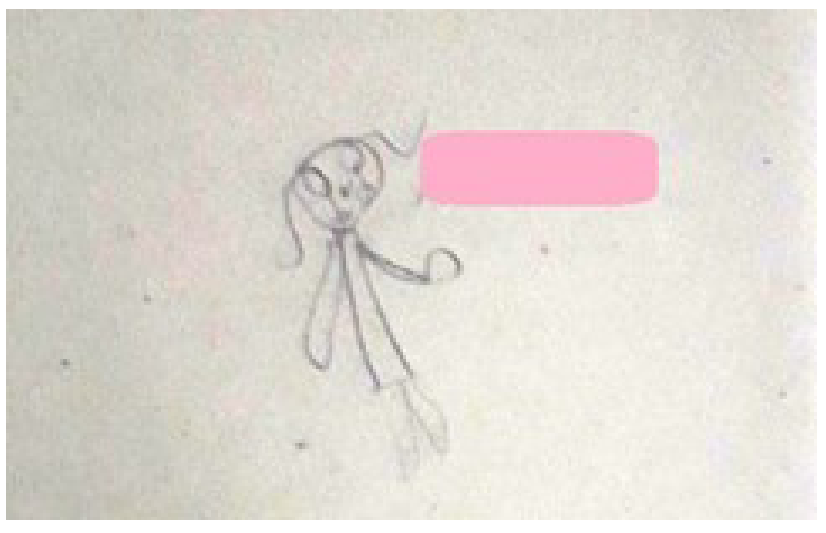

Figure 3 - Drawing made by C3. 8 years old

I feel sad, because I want to go home, but I can't. I need to be treated. But I have to be treated first and then leave hospital. And I will never come back. Crying, here are the tears (pointing to the drawing that represents her with tears going down herface). (C3)

It is known that hospitalization is inevitable in cancer treatment. Moreover, it is painful when children and adolescents are removed from their environment and separated from their families/friends and school. Feelings such as sadness and being imprisoned are present in the statements transcribed here.

\section{Importance of recreational activities during hospitalization}

Children and adolescents described some recreational activities considered important, such as playing cards, playing with dolls and using the internet. Recreational activities provide a distraction for children and adolescents during hospitalization, and least for some time, the diseases ceases to be the central aspect of their lives. In addition, through these activities, patients relive the reality experienced before hospitalization.

Playing UNO with my mom and dad. [...]In this drawing, I wanted to represent myself here, lying there doing nothing in this bed. [...] (So, I like it) To go to the little room, because staying in the bedroom all the time is not very good. (C1)

Then I go to the little room, there is a special little room for that. They organize activities for us. (A11)

What l like most is playing, because of the little room. (C3)

Ah, I wish there was Wi-Fi in here. Because sometimes the children are getting chemotherapy, sometimes for 6 hours, 4 hours, 12 hours and they have nothing to do, you know. And the only place where we can use the internet a little bit is here in the little room. (C2)

Happy? When I go to the little room, play, see people, talk. (C4)

Go there and use the computers (laughs). (A10)

Yes. There is also internet in the little room. It's pretty good for us to have some fun. I really like computer games. I don't really like board games. (A7)

It's not very good, I don't do anything. I can't do anything. But now some women (interns of the Pedagogy Course) are doing some activities with me. (A10)

There's not much to do, but it's cool. You can go in the little room, talk, use the computer, etc. (A13)

Thus, communication, the feeling of isolation and the need for recreational activities during hospitalization permeated the statements of hospitalized children and adolescents with cancer.

\section{DISCUSSION}

One PNH guideline - welcoming - includes communication in the hospitalization process. Welcoming is recognizing the legitimate and real health need of the other. Through active listening, health workers can ensure that users have timely access to technologies suited to their needs, for example ${ }^{(6)}$. The importance of communication between health professionals and patients emerged from the statements of the children and adolescents who participated in this study. The expanded and shared clinic mentioned in the PNH aims to contribute to an approach to illness that considers the subject's singularities and the complexity of the health/ disease process. The expanded shared clinic occurs through a shared construction of diagnoses (other variables, the perception of affections produced in health professional-patient relationships) and a more effective dialogue (between the professionals involved in the treatment and with the users), sharing decisions ${ }^{(6)}$.

It is possible to maintain a horizontal dialogue with each child and adolescent, respecting their level of understanding, according to their different age groups. Through Resolution No. 41 of October 13, 1995, the National Council for the Rights of Children and Adolescents stipulates that children and adolescents have the right to adequate knowledge about their illness, therapeutic care, diagnostics, prognosis, according to their cognitive stage, and with psychological support when necessary ${ }^{(11)}$. 
Hospitalization, for both children and adolescents and their families, often generates negative emotions, such as sadness and stress, which directly affects their coexistence, as they generate uncertainty regarding the diagnosis and the possible end of life. For this reason, health professionals play a crucial role in welcoming this specific public, as it is through involvement that a bond is established professionals and patients, improving the quality of hospitalization, as well as acceptance and adherence to treatment ${ }^{(12)}$.

Communication between health professionals and hospitalized children and adolescents is perceived as a challenge, since interactions of the health team with the family tend to be reduced, as patients begin to become stable. The information transmitted to patients and family caregivers generates proximity, comfort and support. Such information, in addition to generating knowledge, contributes to a better understanding of present and future events, because many family members have feelings of denial and fear in the face of strangers taking control of their children's health, or else they feel useless because they are not able to take care of their children. Children and adolescents' awareness about their diseases and limitations should be considered. Therefore, these patients should be properly informed in the hospital and at school about their rights and duties ${ }^{(13)}$.

Moreover, toys and recreation are strong allies of health professionals in a responsive communication with children and family members, favoring the welcoming process. Through this technique, health professionals can access the children's world more precisely, contributing to better coping with the disease ${ }^{(14)}$. The use of recreational strategies in the care of hospitalized children, in addition to being a form of entertainment and distraction for children, can minimize suffering, facilitating the execution of procedures and reaffirming the ambience guideline proposed by the National Humanization Policy ${ }^{(15)}$.

In the hospital playroom, children admitted to hospital for cancer treatment have contact with games that require less physical effort, such as puzzles, video games, games on the mobile phone and drawing. These games, as well as the social interaction in this space, favor children's development. Health professionals, especially nurses, who work in a hospital setting, should develop skills that facilitate and promote recreation in the hospital environment, as this is essential for children's development ${ }^{(16)}$.

The National Council for the Rights of Children and Adolescents provides for welcoming and respect for the peculiarities of these individuals. Therefore, recreation is a guaranteed right ${ }^{(11)}$. Recreational activities contribute to children's well-being and are also a non-pharmacological pain relief resource that generates a sensation of "feeling better", since feelings like pleasure, joy and contentment help to maintain a good quality of life for children. Playing can also help prepare children for medical procedures ${ }^{(17)}$.

Games are strong allies for children in the hospitalization process, as they allow these patients to have a better experience and perceive the disease in a more positive way. The multidisciplinary team should encourage, whenever possible, the use of toys and games in a therapeutic way, because they make children feel more welcomed and at home, close to friends, school and parents, helping in the healing process ${ }^{(14)}$.

Cancer requires adaptations to the routine of children and adolescents, who need to face difficult moments. Recreational activities during hospitalization are an efficient way to face these moments. The use of toys/recreational activities to welcome these patients and their families by health professionals can make the hospitalization process less painful. Also, recreational activities enable health professionals to perceive anxiety and distress, bringing more security, peace and acceptance of treatment and hospitalization ${ }^{(14)}$.

The PNH sets parameters for policy adherence in the hospital environment, including: multidisciplinary healthcare team (with at least one doctor and one nurse) for the follow-up of hospitalized patients and with an agreed schedule for assisting the families and/or their social networks; de-hospitalization mechanisms, aiming at alternatives to hospital practices such as home care; he guarantee of continuous assistance with referral and counter-referral systems; permanent education plan for workers with humanization themes ${ }^{(6)}$. Such mechanisms can contribute to making the hospital environment less hostile for children and adolescents.

The removal of patients from family, friends and school, associated with the impossibility of this social interaction because of the hospitalization process, is an important factor for the isolation of children and adolescents. In the context of hospitalization, it is also suggested that social interaction can be beneficial by providing more knowledge about the disease, reducing isolation and improving adaptation. Social interaction is also an important need that is not being met during hospitalization, as many patients fear long periods of isolation and are also concerned with body image changes caused by numerous drug and radiation treatments they have undergone ${ }^{(18)}$.

Adolescents usually find it difficult sharing psychosocial issues with health professionals. Many professionals pose only specific questions about the physical body, based on a biomedical model, which focuses on the patient's pathology, ignoring other aspects. As a result, social and cultural issues, beliefs and values are not considered in the communication process ${ }^{(19)}$. 
Children and adolescents undergoing cancer treatment have knowledge and perception about their pain and about individual and subjective aspects of the disease, as well as about physical and emotional pain associated to therapeutic procedures and the possible side effects of chemotherapy and radiotherapy. Therefore, in life stages such as adolescence and adulthood, these patients may be traumatized by hospitalizations and develop mental illness ${ }^{(20)}$.

These patients have or acquire their own language to communicate their pain and complaints, which somehow helps professionals in the management of care to this clientele, minimizing future conflicts between family members, patients and professionals ${ }^{(20)}$.

The ambience guideline proposed by the National Humanization Policy concerns the provision of healthy, welcoming and comfortable spaces that respect the privacy of patients, promote changes in work processes, and which are also places for people to meet. Ambience arises from the shared discussion of the architectural design, renovations and use of spaces according to the needs of users and workers of each service. It is a guideline that can improve health care work ${ }^{(6)}$. In this context, ambience can make the hospital environment less traumatic for children and adolescents during hospitalization.

\section{口CONCLUSIONS}

Care in the hospitalization of children and adolescents undergoing cancer treatment stems from the importance of communication with health professionals and the need to implement recreational activities to reduce the feeling of social isolation and distance from friends, other family members and the school.

In this sense, the importance of incorporating the guidelines and principles of the National Humanization Policy (PNH) stands out, especially regarding welcoming, understood as an attitude that health professionals must have in all their meetings with patients. Childhood cancer is considered complex, and its treatment requires a multidisciplinary team. Thus, the expanded clinic is perceived as necessary. Finally, there is ambience, which concerns the construction of healthy and welcoming spaces, and makes the hospital environment more humanized. The limitations of this study are associated to the small sample size (analysis and description of the local experience). However, the PNH is a national policy, and the results of the present study can contribute to its application in different scenarios of the country.
Contributions to nursing care are mainly related to the statement that professionals' communication with children and the use of recreation are essential strategies in pediatric inpatient services. These findings reinforce the need to implement the guidelines and principles of the National Humanization Policy in oncology units for children and adolescents. The need to improve communication and the need for recreation as a fundamental axis of pediatric nursing are reiterated.

\section{REFERENCES}

1. Ministério da Saúde (BR). Instituto Nacional de Câncer José Alencar Gomes da Silva. Síntese de resultados e comentários. In: Estimativa de câncer no Brasil: 2016. Rio de Janeiro: INCA; 2015 [cited 2016 Sep 26]. p. 31-53. Available from: http://santacasadermatoazulay.com.br/wp-content/uploads/2017/06/ estimativa-2016-v11.pdf

2. Ministério da Saúde (BR). Morbidade Hospitalar do SUS - Por Local de Internação - Brasil. Óbitos por Faixa Etária. Segundo Capítulo CID-10. Período: 2008-2016. Brasília, DF: Datasus; 2017 [cited 2017 Jul 15]. Available from: http://tabnet.datasus.gov.br/cgi/tabcgi.exe?sih/cnv/niuf.def

3. Borghi CA, Szylit R, Ichikawa CRF, Baliza MF, Camara UTJ, Frizzo HCF. Use of social networking websites as a care instrument for hospitalized adolescents. Esc Anna Nery. 2018;22(1):e20170159. doi: https://doi. org/10.1590/2177-9465-ean-2017-0159

4. Silva L, Baran F, Merces N. Music in the care of children and adolescents with cancer: integrative rewiew. Texto Contexto Enferm. 2016;25(4):e1720015. doi: https://doi.org/10.1590/0104-07072016001720015

5. Guimarães TM, Silva LF, Santo FHE, Moraes JRMM, Pacheco STA. Palliative care in paediatric oncology in nursing education. Rev Gaúcha Enferm. 2017;38(1):e65409. doi: https://doi.org/10.1590/1983-1447.2017.01.65409

6. Ministério da Saúde (BR). Secretaria-Executiva. Núcleo Técnico da Política Nacional de Humanização. HumanizaSUS, política nacional de humanização: documento base para gestores e trabalhadores do SUS. 4. ed. Brasília: Ministério da Saúde; 2010 [cited 2017 Jul 15]. Available from: https://bvsms.saude.gov. br/bvs/publicacoes/humanizasus_documento_gestores_trabalhadores_sus. pdf

7. Santos PM, Silva LF, Depianti JRB, Cursino EG, Ribeiro CA. Nursing care through the perception of hospitalized children. Rev Bras Enferm. 2016;69(4):603-9. doi: https://doi.org/10.1590/0034-7167.2016690405i

8. Emidio SCD, Morais RJL, Oliveira PNM, Bezerra RS. Percepção de crianças hospitalizadas acerca do tratamento oncológico. Rev Fund Care Online. 2018;10(4):1141-9. doi: https://doi.org/10.9789/2175-5361.2018. v10i4.1141-1149

9. Moreira H, Caleffe LG. Metodologia da pesquisa para o professor pesquisador. Rio de Janeiro: DP\&A; 2008.

10. Braun V, Clarke V. Using thematic analysis in psychology. Qual Res Psychol. 2006;3(2):77-101. doi: https://doi.org/10.1191/1478088706qp0630a 
11. Conselho Nacional dos Direitos da Criança e do Adolescente (BR). Resoluções, junho de 1993 a setembro de 2004. Brasília: Secretaria Especial dos Direitos Humanos; 2004 [cited 2019 Dec 28]. Available from: https://www.gov.br/ $\mathrm{mdh} / \mathrm{pt}$-br/acesso-a-informacao/participacao-social/conselho-nacionaldos-direitos-da-crianca-e-do-adolescente-conanda/resolucoes/resolucoes1-a-99.pdf

12. Nascimento FGP, Silva VR. Importance of the visit to the childin a pediatric intensive care: opinion of the accompanyers. Rev Enferm UFPE on line. 2017 [cited 2019 Dec 11];11(10):3920-7. Available from: https://periodicos.ufpe.br/ revistas/revistaenfermagem/article/view/25367/24402

13. Badarau DO, De Clerca E, Wangmo T, Dragomir M, Miron I, Kuhne T, et al. Cancer care in Romania: challenges and pitfalls of children's and adolescents' multifaceted involvement. J Med Ethics. 2016 [cited 2020 Aug 15];42(12):75761. doi: https://doi.org/10.1136/medethics-2016-103418

14. Dias PLM, Silva IP.The use of the toy during the treatment of children with cancer: perceptions of the multidisciplinary team. Rev Bras Cancerol. 2018;64(3):311-8. doi: https://doi.org/10.32635/2176-9745.RBC.2018v64n3.28

15. Paula GK, Góes FGB, Silva ACSS, Moraes JRMM, Silva LF, Silva MA. Play strategies in nursing care for the hospitalizaed child. Rev Enferm UFPE on line. 2019 [cited 2020 Aug 15];13:e238979. Available from: https://periodicos.ufpe.br/revistas/ revistaenfermagem/article/view/238979/32465
16. Silva LF, Cabral IE. Rescuing the pleasure of playing of child with cancer in a hospital setting. Rev Bras Enferm. 2015;68(3):337-42. doi: https://doi. org/10.1590/0034-7167.2015680303i

17. Morais GSN, Costa SFG, França JRF de Sá, Duarte MCS, Lopes MEL, Batista PSS. Existential experience of children undergoing chemotherapy regarding the importance of playing. Rev Rene. 2018;19:e3359. doi: https://doi. org/10.15253/2175-6783.2018193359

18. Christiansen HL, Bingen K, Hoag JA, Karst JS, Velázquez-Martin B, Barakat LP. Providing children and adolescents opportunities for social interaction as a standard of care in pediatric oncology. Pediatr Blood Cancer. 2015;62 Suppl 5:S724-49. doi: https://doi.org/10.1002/pbc.25774

19. Effendy C, Vissers K, Tejawinata S, Vernooij-Dassen M, Engels Y. Dealing with symptoms and issues of hospitalized patients with cancer in indonesia: the role of families, nurses, and physicians. Pain Pract. 2015;15(5):441-6. doi: https:// doi.org/10.1111/papr.12203

20. Siqueira HBOM, Pelegrin AKAP, Gomez RRF, Silva TCR, Sousa FAEF. Percepções de adolescentes com câncer: pesquisa fenomenológica. Rev Abordagem Gestalt. 2015 [citado 2019 dez 19];21(1):13-21. Disponível em: http://pepsic.bvsalud. org/scielo.php?script=sci_arttext\&pid=\$1809-68672015000100003 


\section{- Authors' contribution:}

Conceptualization: Raíra Lopes Amaral de Souza, Cintia Flôres Mutti, Eliane Tatsch Neves.

Formal analysis: Raíra Lopes Amaral de Souza, Cintia Flôres Mutti, Raíssa Passos dos Santos, Eliane Tatsch Neves.

Investigation: Raíra Lopes Amaral de Souza, Cintia Flôres Mutti, Raíssa Passos dos Santos, Diúlia Calegari de Oliveira, Eliane Tatsch Neves.

Methodology: Raíra Lopes Amaral de Souza, Cintia Flôres Mutti, Raíssa Passos dos Santos, Aline Cristiane Cavicchioli, Leonardo Bigolin Jantsch, Eliane Tatsch Neves.

Validation: Raíra Lopes Amaral de Souza, Aline Cristiane Cavicchioli Okido, Leonardo Bigolin Jantsch, Eliane Tatsch Neves.

Writing - original draft preparation: Raíra Lopes Amaral de Souza, Diúlia Calegari de Oliveira, Aline Cristiane Cavicchioli Okido, Leonardo Bigolin Jantsch, Eliane Tatsch Neves.

Writing-review and editing: Raíra Lopes Amaral de Souza, Aline Cristiane Cavicchioli, Leonardo Bigolin Jantsch, Eliane Tatsch Neves.

\section{- Corresponding author:}

Leonardo Bigolin Jantsch

E-mail: leonardo.jantsch@ufsm.br

Associate editor:

Jéssica Machado Teles

Editor-in-chief:

Maria da Graça Oliveira Crossetti 